\title{
Faunal Diversity of Durgadahalli Lake of Tumakuru, Karnataka State, India
}

Keywords: Zooplanktons; Arthropods; Mollusca; Amphibia; Reptilia; Physico-chemical parameter; Durgadahalli Lake

\begin{abstract}
The aquatic organisms are the good indicators of health of an aquatic ecosystem and represent the balanced ecosystem. The present study was conducted to understand the current status of faunal diversity in Durgadahalli Lake, located in the North-East of Tumakuru district, at distance of $15 \mathrm{~km}$ from Tumakuru city in Karnataka. It lies at $13^{\circ} 13^{\prime} 56^{\prime \prime} \mathrm{N}$ latitude and $77^{\circ} 25^{\prime} 30^{\prime \prime}$ E longitude. It receives water mainly from rain-fall with an average of $620 \mathrm{~mm}$ and from Jayamangalli river. The Lake comparatively smaller with rich aquatic faunal diversity and recorded 20 species of zooplankton, 9 species of aquatic insects belonging to Hemiptera, Coleoptera, Odonata and Diptera,One molluscan shell, 2 amphibia species (frog) and one reptilian species (turtle).The water collected and analyzed from five selective sampling stations of the Lake from 2016 to 2019. Not many reports are available on Durgadahalli Lake with respect to faunal diversity. Keeping it in mind, we have selected Durgadahalli Lake for the present study on ecology and aquatic faunal diversity.
\end{abstract}

\section{Introduction}

Biological diversity is a part of our daily lives and livelihood having numerous values in agriculture, medicine, food and industry. Biodiversity maintains the evolutionary processes and ecological balance, millions of species which constitute biodiversity have their own intrinsic value. "Biodiversity means totality of genes, species and ecosystem in a region" [1]. Out of the total ecosystem network, freshwater ecosystems are receiving more attention worldwide because of their overwhelming economic importance. The food chain in Lake ecosystem is very simple, phytoplankton and aquatic vegetation serve as primary producers, zooplankton as primary consumers, small fishes as secondary consumers and large fishes as tertiary consumers. Plankton is the most sensitive floating community which is being the first target for water pollution, thus any undesirable change in aquatic ecosystem first affects diversity as well as biomass of this community. The phylum Arthropoda is the largest phylum of kingdom Animalia, which includes insects, and two-thirds of all named species on Earth are arthropods. The class Insecta includes 11 different orders, out of which 4 orders namely Hemiptera, Coleoptera, Odonata and Diptera include common freshwater insects.

In the freshwater environment, phylum Mollusca plays a vital role in the aquatic ecosystem functioning [2]. Molluscans commonly found in ponds, Lakes, paddy fields, quiet water pools etc., and remain attached to submerged vegetation, rocks, sticks, bricks etc. Molluscs are good indicators of water quality and status of aquatic system [3]. There are estimated 5000 species with valid descriptions in and 10000 undescribed species [4]. 370 species are reported from British India, Mynamar and Ceylon [5,6] consolidated the information on freshwater molluscs and published a "Handbook of

\section{Environmental Studies}

\author{
Shivaraju* and Venkateshwarlu M \\ Department of Studies and Research in Applied Zoology, Jnana \\ Sahyadri, Karnataka, India

\section{*Address for Correspondence} \\ Shivaraju, Department of Studies and Research in Applied Zoology, \\ Jnana sahyadri, Shankaraghatta, Kuvempu University, Shivamogga-577 \\ 451, Karnataka, India; Email: 1993shivarajugiri@gmail.com

\section{Submission: 13 May, 2021 \\ Accepted: 15 June 2021} \\ Published: 20 June 2021 \\ Copyright: ( 2021 Shivaraju et al. This is an open access article \\ distributed under the Creative Commons Attribution License, which \\ permits unrestricted use, distribution, and reproduction in any medium, \\ provided the original work is properly cited.
}

Freshwater Molluscs of India” with 195 species recorded from India and neighboring areas. Amphibians are the organisms which live both on land and in aquatic media. In the universe, amphibians are represented by three living orders namely Anura, Urodela and Apoda. The order Anura comprises of frogs and toads with 6706 species, order Urodela has salamanders and newts with 693 species and order Apoda have limbless amphibians with 205 species worldwide. Thus, 7604 species of amphibians are known globally, of which 386 species belongs to 59 genera and 15 families of all three living orders. 345 species of frogs and toads, 2 species of salamanders and 39 species of caecilans or limbless amphibians are known from India. Reptiles are found in all kinds of environments except severe cold regions. Out of 566 species of reptiles, 3 species of crocodiles, 33 species of Testudineous, 234 species of lizards and 296 species of snakes are known from India

\section{Materials and Methods}

\section{Study Area}

Durgadahalli Lake located in the North-Eastern part of Tumakuru taluk, at a distance of $15 \mathrm{~km}$ from Tumakuru city in Karnataka. It lies at $13^{\circ} 13^{\prime} 56^{\prime \prime} \mathrm{N}$ latitude, $77^{\circ} 25^{\prime} 30^{\prime \prime}$ E longitude with water spread area of about 15.60 hectares and its average depth is 1.8 to 2.0 meters along the bund (Figure 1). It receives water mainly from rain-fall and from

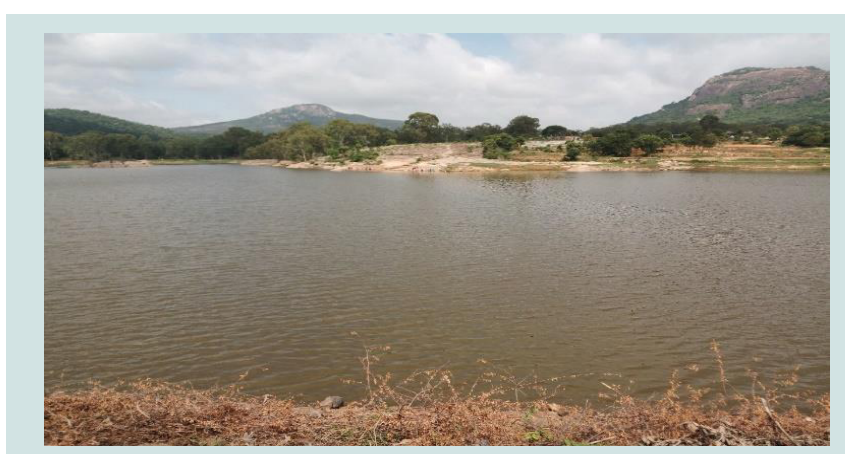

Figure 1: Durgadahalli lake. 
river Jayamangalli. The water is mainly used for agriculture, domestic and drinking as well as culture fishes. The total catchment area of is 17.25sq.km and height 10.4 to $10.6 \mathrm{~m}$. The average rain-fall of $620 \mathrm{~mm}$ and soil type is sand/gravel.

\section{Methodology}

Water Analysis: Water samples were collected from selected sites of the Lake. The sampling was usually carried out from 8:00 am to 10:00 am, once in a quarter from 2016-2019. The water samples were collected directly from the surface layer in plastic canes to avoid unpredictable changes. The physicochemical analysis of samples was done in the lab by adapting the procedure prescribed by) [7] and [8].

Faunal Diversity: The D-frame and O-frame aquatic nets were used for collection of aquatic animals (Arthropoda, Mollusca, Fishes, Amphibia). The size of the mesh or sieve (pore size of the net) varies from $20-500 \mu \mathrm{m}$ depending upon the size of the organism. The collection from lentic habitats was usually done by sweeping the net vigorously and carefully lifted with the entire mass of macrophytes or sediments. The flat side of the D-frame net was placed on the bottom of the Lake and the vegetation was disturbed by vigorous dragging the net, which facilitated the different aquatic fauna to be swept into the net. Same techniques were used for collection of different fauna along the catchment area of the Lake, by always sweeping the net upstream and letting the current to carry the animals into the net.

\section{Results and Discussion}

\section{Water analysis}

In Durgadahalli Lake, water temperature ranged between $25.5 \mathrm{oC}$ to $25.83^{\circ} \mathrm{C}$ i.e., not much variable. The $\mathrm{pH}$ was slightly acidic, neutral or alkaline in nature depending on season and time of water collection throughout the study period and ranged from 6.9 to 7.3. The range of biological oxygen demand (BOD) and dissolved oxygen (DO) varied between 3.06 to $3.15 \mathrm{mg} / \mathrm{l}$ and 7.23 to $7.32 \mathrm{mg} / \mathrm{l}$ respectively. The chemical oxygen demand (COD) ranged from 30.67 to $30.92 \mathrm{mg} / \mathrm{l}$, the electrical conductivity from 252.7 to $254.17 \mu \mathrm{s} / \mathrm{cm}$ in Lake. Turbidity ranged from 8.35 to $8.867 \mathrm{NTU}$. Total hardness, total suspended solids, total dissolved solids and total solids ranged from 42.33 to $42.75 \mathrm{mg} / \mathrm{l}, 14.083$ to $15.2 \mathrm{mg} / \mathrm{l}, 170.33$ to $170.833 \mathrm{mg} / \mathrm{l}$ and 185.75 to $189.167 \mathrm{mg} / \mathrm{l}$ respectively. The water dissolved metals such as Nickel, Chromium, Arsenic, Lead, Cadmium, Zinc, Iron, Manganese, Copper was recorded below detection level (BDL) with little bit muddy and slight fishy odour. The results of water analysis showed that, it is good for growth and survival of aquatic organisms. Noun predictable change was seen in the water throughout the study period (Tables 1,2).

Environmental factors like water quality, altitude and nutrient supplements influenced the diversity of aquatic fauna and also showed great impact on species richness [9]. The same pattern was also reported by [10]. The species richness was found to be low at higher elevation and high at lower elevation, which is similar to results of present study in Durgadahalli Lake. Water temperature is another factor that provides favorable conditions for high algal production which directly influences herbivore fish [11-17] considered water temperature as the most important factor of environmental variability. The agricultural runoff around the Lakes increased concentration of ammonia and nitrogen released from the synthetic fertilizers which impact the aquatic life $[18,19]$.

\section{Diversity of Fauna}

In this study, a total of 20 species of zooplanktons were recorded from the Durgadahalli Lake. Out of which 14 are rotifers, 4 cladocerans and 2 copepods. Among the rotifers, family Brachionidae (11 species) with Genus Brachionu shaving 08 species represented the maximum diversity. The families Hexarthridae, Filiniidae and Asplanchnidae are represented with one species each. In cladocera, families Daphniidae (02 species), Moinidae (01 species) and Chydoridae (01 species) are recorded in this Lake. In copepoda, family Diaptomidae has two species (Table 3 ). Most commonly occurring species in this Lake included Brachionus angularis, Brachionus caudatus, Keratella tropica, Filinia longiseta, Ceriodaphnia cornuta and Moina micrura. The rotifer showed highest number of species as well as copepod showed lowest number of species of zooplankton in the study area. The Jaccard similarity index ( $\mathrm{J}$ ) for Diversity of zooplankton is 0.4583 (Table 6). Similar results were also reported in Ameenpur tank, Ameenpur village, Medak district, Telangana by [20] reported family Rotifera found to be abundant followed by order Cladocera and Copepoda respectively. [21] reported rotifers to be more predominant than other zooplankton communities, especially family Brachionidae and Lecanidae in the chosen pond at Medak district. They observed a significant relationship between Physico-chemical parameters and zooplankton indices. [22] reported Rotifera representing highest number of species followed by Cladocera, Copepoda, Ostracoda and Insecta respectively. [23] investigated the Osmansagar reservoir in Telangana and reported highest population density of zooplankton which was due to rotifer and copepods where rotifers were most dominant followed by Cladocerans and Copepods.

There are nine different Insects were reported in Durgadahalli Lake, genus Hydrometra and Perittopus belonging to families Hydrometridae and Vellidae respectively (Table 4). Genus Lacconectus of family Dytiscidae and genus Ochthebius of family Hydraenidae are found in Durgadahalli Lake (Table 4).The identified species are Libellago andamanensis, Gomphidia kodaguensis and Trameatransmarine belonging to families Chlorocyphidae, Gomphidae and Libellulidae respectively (Table 4). Genus Brillia and Chironomus of family Chironomidae (Table 4) were also reported in study area. The Jaccard similarity index (J) for Diversity of insects is calculated as 0.256 (Table 6). The diversity and distribution of this groups helps to understand the functional aspects of community structure and provide the baseline data for effective conservation and management of aquatic ecosystem. [24,25], mentioned approximately 4,656 species of aquatic and semi-aquatic bugs belonging to 20 families and 326 genera inhabit freshwater globally, and more than 1,100 species remain undescribed [26]. Out of which India is represented by 318 species under 82 genera and 18 families [27-30], Hungerford and Matsuda [31,32] and Thirumalai (1999) observed and reported similar results. [33,34] also reported diversity of aquatic insects belonging to Hemiptera, Odonata, Coleoptera and Diptera.

In the present study reported shell of Unio, identified as Lamellidens consobrinus [35] (Figure 2) belonging to class Bivalvia, order Unionida and family Unionidae (Table 5). Jaccard similarity 


\section{ISSN: 2471-4879}

Table 1: Season wise Physico chemical analysis of Durgadahalli Lake from 2016-19.

\begin{tabular}{|c|c|c|c|c|c|c|c|c|c|c|c|}
\hline \multirow[b]{2}{*}{$\begin{array}{l}\text { SL. } \\
\text { No }\end{array}$} & \multirow[b]{2}{*}{ Water parameters } & \multirow[b]{2}{*}{ Unit } & \multicolumn{3}{|c|}{ 2016-17 } & \multicolumn{3}{|c|}{$2017-18$} & \multicolumn{3}{|c|}{ 2018-19 } \\
\hline & & & $\begin{array}{l}\text { Winter } \\
\text { (Dec to } \\
\text { Feb) }\end{array}$ & $\begin{array}{c}\text { Summer or } \\
\text { pre-monsoon } \\
\text { (March to May) }\end{array}$ & $\begin{array}{l}\text { Monsoon or } \\
\text { rainy (June } \\
\text { to Sep) }\end{array}$ & $\begin{array}{l}\text { Winter } \\
\text { (Dec to } \\
\text { Feb) }\end{array}$ & $\begin{array}{c}\text { Summer or } \\
\text { pre-monsoon } \\
\text { (March to May) }\end{array}$ & $\begin{array}{l}\text { Monsoon or } \\
\text { rainy (June } \\
\text { to Sep) }\end{array}$ & $\begin{array}{l}\text { Winter } \\
\text { (Dec to } \\
\text { Feb) }\end{array}$ & $\begin{array}{c}\text { Summer or } \\
\text { pre-monsooon } \\
\text { (March to May) }\end{array}$ & $\begin{array}{l}\text { Monsoon or } \\
\text { rainy (June } \\
\text { to Sep) }\end{array}$ \\
\hline 1 & $\mathrm{pH}$ & $\begin{array}{l}\mathrm{pH} \\
\text { unit }\end{array}$ & 7 & $6.9-7.0$ & $7.1-7.2$ & 7.1 & 7 & 7.1-7.3 & 7 & 7.1-7.2 & 7 \\
\hline 2 & $\begin{array}{c}\text { Biological Oxygen } \\
\text { Demand (BOD) } \\
\left(3 \text { days @2 } 27^{\circ} \mathrm{C}\right)\end{array}$ & $\mathrm{mg} / \mathrm{l}$ & 3.2 & 3 & 3 & 3.25 & 3 & 3.05 & 3.4 & 3.05 & 3 \\
\hline 3 & $\begin{array}{c}\text { Dissolved Oxygen } \\
\text { (DO) }\end{array}$ & $\mathrm{mg} / \mathrm{l}$ & 7.35 & 7.15 & 7.45 & 7.35 & 7.1 & 7.25 & 7.5 & 7.1 & 7.35 \\
\hline 4 & $\begin{array}{c}\text { Chemical Oxygen } \\
\text { Demand (COD) }\end{array}$ & $\mathrm{mg} / \mathrm{l}$ & 28.505 & 31.5 & 32 & 28.75 & 32.5 & 31.5 & 28.5 & 31.5 & 32.5 \\
\hline 5 & Conductivity & $\mu \mathrm{s} / \mathrm{cm}$ & 247.625 & 265.5 & 245 & 247 & 267.5 & 248 & 246.5 & 265 & 247 \\
\hline 6 & Nitrate Nitrogen & $\mathrm{mg} / \mathrm{l}$ & 0.9 & 1 & 0.89 & 1 & 1.1 & 1 & 1 & 1.05 & 1.05 \\
\hline 7 & $\begin{array}{l}\text { Ammonical } \\
\text { Nitrogen }\end{array}$ & $\mathrm{mg} / \mathrm{l}$ & 0.195 & 0.225 & 0.425 & 0.2 & 0.275 & 0.45 & 0.25 & 0.225 & 0.475 \\
\hline 8 & Turbidity & NTU & 7.5 & 8.05 & 9.5 & 7.6 & 8.2 & 9.5 & 8.75 & 9.35 & 8.5 \\
\hline 9 & Total Hardness & $\mathrm{mg} / \mathrm{l}$ & 39.5 & 43 & 44.5 & 39.25 & 44 & 45 & 40 & 43 & 44.5 \\
\hline 10 & Calcium (CaCO3) & $\mathrm{mg} / \mathrm{l}$ & 23.5 & 24.5 & 22.5 & 23.5 & 25.5 & 24 & 22.5 & 24.5 & 26 \\
\hline 11 & Chloride $(\mathrm{Cl})$ & $\mathrm{mg} / \mathrm{l}$ & 16.5 & 17.5 & 14.5 & 16.7 & 18 & 15.75 & 17.4 & 17.75 & 16.25 \\
\hline 12 & Sodium (Na) & $\mathrm{mg} / \mathrm{l}$ & 29 & 31.5 & 23 & 29.6 & 32 & 22.5 & 29.25 & 32 & 22.5 \\
\hline 13 & Potassium (K) & $\mathrm{mg} / \mathrm{l}$ & 7.5 & 8.4 & 7.5 & 7.75 & 8.9 & 7.6 & 7.5 & 8.8 & 7.85 \\
\hline 14 & Sulphate (SO4) & $\mathrm{mg} / \mathrm{l}$ & 11 & 10.5 & 8.5 & 10.5 & 11 & 8.75 & 10.75 & 10.25 & 9 \\
\hline 15 & $\begin{array}{l}\text { Total Suspended } \\
\text { Solids (TSS) }\end{array}$ & $\mathrm{mg} / \mathrm{l}$ & 13 & 14.5 & 18 & 13 & 14 & 16.6 & 12.5 & 14.25 & 15.5 \\
\hline 16 & $\begin{array}{l}\text { Total Dissolved } \\
\text { Solids (TDS) }\end{array}$ & $\mathrm{mg} / \mathrm{l}$ & 164 & 185 & 162 & 165 & 186 & 160 & 162.5 & 182.5 & 167.5 \\
\hline 17 & Fluoride (F) & $\mathrm{mg} / \mathrm{l}$ & 0.17 & 0.2 & 0.145 & 0.2 & 0.21 & 0.18 & 0.195 & 0.21 & 0.18 \\
\hline 18 & Total solids & $\mathrm{mg} / \mathrm{l}$ & 182.75 & 194.5 & 180 & 183 & 199.5 & 181.5 & 181 & 200 & 186.5 \\
\hline 19 & Carbonate $\left(\mathrm{CO}_{3}\right)$ & $\mathrm{mg} / \mathrm{l}$ & 0.6 & 0.65 & 0.45 & 0.6 & 0.85 & 0.525 & 0.65 & 0.95 & 0.55 \\
\hline 20 & $\begin{array}{c}\text { Bicarbonate } \\
\left(\mathrm{HCO}_{3}\right)\end{array}$ & $\mathrm{mg} / \mathrm{l}$ & 4.5 & 4.4 & 4.15 & 4.6 & 4.35 & 4.25 & 4.6 & 4.25 & 4.2 \\
\hline 21 & Colour & & $\begin{array}{l}\text { Little bit } \\
\text { muddy }\end{array}$ & Little bit muddy & $\begin{array}{l}\text { Little bit } \\
\text { muddy }\end{array}$ & $\begin{array}{l}\text { Little bit } \\
\text { muddy }\end{array}$ & Little bit muddy & $\begin{array}{l}\text { Little bit } \\
\text { muddy }\end{array}$ & $\begin{array}{l}\text { Little bit } \\
\text { muddy }\end{array}$ & Little bit muddy & $\begin{array}{l}\text { Little bit } \\
\text { muddy }\end{array}$ \\
\hline 22 & Odour & & $\begin{array}{l}\text { Slight } \\
\text { Fishy }\end{array}$ & Slight Fishy & Slight Fishy & $\begin{array}{l}\text { Slight } \\
\text { Fishy }\end{array}$ & Slight Fishy & Slight Fishy & $\begin{array}{l}\text { Slight } \\
\text { Fishy }\end{array}$ & Slight Fishy & Slight Fishy \\
\hline 23 & Temperature & ${ }^{\circ} \mathrm{C}$ & 26.25 & 25.25 & 25 & 26.25 & 25.4 & 25.75 & 25.5 & 26.25 & 25.75 \\
\hline
\end{tabular}

Table 2: Correlation Coefficient of Physico-Chemical characteristics of Durgadahalli Lake from 2016-2019.

\begin{tabular}{|c|c|c|c|c|c|c|c|c|c|c|c|c|c|c|c|c|c|c|c|c|c|}
\hline & $\mathrm{pH}$ & BOD & DO & COD & EC & $\mathrm{NO}_{3}-\mathrm{N}$ & $\mathrm{NH}_{3}-\mathrm{N}$ & Turbidity & TH & $\mathrm{Ca}$ & $\mathrm{Cl}$ & $\mathrm{Na}$ & K & $\mathrm{SO}_{4}$ & TSS & TDS & $\mathbf{F}$ & TS & $\mathrm{CO}_{3}$ & $\mathrm{HCO}_{3}$ & oC \\
\hline pH & 1 & 0.05 & 0.05 & 0.05 & 0.05 & 0.05 & 0.05 & 0.05 & 0.05 & 0.05 & 0.05 & 0.05 & 0.05 & 0.05 & 0.05 & 0.05 & 0.05 & 0.05 & 0.05 & 0.05 & 0.05 \\
\hline BOD & & 1 & -0.219 & -0.33 & -0.437 & 0.05 & 0.05 & 0.158 & -0.212 & 0.282 & 0.469 & 0.23 & 0.467 & 0.331 & -0.306 & -0.333 & 0.05 & -0.231 & 0.316 & 0.661 & 0.204 \\
\hline DO & & & 1 & -0.38 & -0.038 & 0.05 & 0.05 & -0.499 & -0.372 & -0.636 & -0.624 & -0.385 & -0.814 & 0.031 & -0.004 & -0.333 & 0.05 & -0.537 & \begin{tabular}{|c|}
-0.693 \\
\end{tabular} & -0.331 & -0.072 \\
\hline COD & & & & 1 & 0.349 & 0.05 & 0.05 & 0.34 & 0.911 & 0.552 & \begin{tabular}{|l|} 
\\
\end{tabular} & -0.156 & 0.243 & -0.29 & \begin{tabular}{|l|l|} 
\\
\end{tabular} & 0.407 & 0.05 & \begin{tabular}{|l|l|}
0.482 \\
\end{tabular} & 0.189 & -0.219 & -0.371 \\
\hline EC & & & & & 1 & 0.05 & 0.05 & -0.343 & 0.136 & 0.119 & \begin{tabular}{|l|}
0.167 \\
\end{tabular} & 0.524 & 0.006 & 0.422 & -0.115 & 0.907 & 0.05 & \begin{tabular}{|l|l|} 
& 0.794 \\
\end{tabular} & 0.063 & -0.349 & -0.212 \\
\hline $\mathrm{NO}_{3}-\mathrm{N}$ & & & & & & 1 & 0.05 & 0.05 & 0.05 & 0.05 & 0.05 & 0.05 & 0.05 & 0.05 & 0.05 & 0.05 & 0.05 & 0.05 & 0.05 & 0.05 & 0.05 \\
\hline $\mathrm{NH}_{3}-\mathrm{N}$ & & & & & & & 1 & 0.05 & 0.05 & 0.05 & 0.05 & 0.05 & 0.05 & 0.05 & 0.05 & 0.05 & 0.05 & 0.05 & 0.05 & 0.05 & 0.05 \\
\hline Turbidity & & & & & & & & 1 & 0.547 & 0.261 & 0.29 & -0.173 & 0.528 & -0.594 & 0.494 & -0.218 & 0.05 & 0.044 & 0.4 & 0.12 & 0 \\
\hline TH & & & & & & & & & 1 & 0.583 & 0.105 & -0.338 & 0.293 & -0.443 & 0.818 & 0.162 & 0.05 & 0.286 & 0.179 & -0.16 & -0.192 \\
\hline $\mathrm{Ca}$ & & & & & & & & & & 1 & 0.672 & 0.154 & 0.653 & 0.192 & 0.204 & 0.259 & 0.05 & 0.466 & 0.522 & 0.353 & 0.177 \\
\hline $\mathrm{Cl}$ & & & & & & & & & & & 1 & 0.610 & 0.803 & 0.4 & -0.278 & 0.286 & 0.05 & 0.556 & 0.677 & 0.561 & 0.25 \\
\hline $\mathrm{Na}$ & & & & & & & & & & & & 1 & 0.540 & 0.698 & -0.609 & 0.659 & 0.05 & 0.658 & 0.560 & 0.414 & -0.136 \\
\hline K & & & & & & & & & & & & & 1 & 0.165 & -0.035 & 0.282 & 0.05 & 0.475 & 0.813 & 0.593 & -0.027 \\
\hline $\mathrm{SO}_{4}$ & & & & & & & & & & & & & & 1 & -0.645 & 0.433 & 0.05 & 0.296 & 0.154 & 0.381 & -0.028 \\
\hline TSS & & & & & & & & & & & & & & & 1 & -0.148 & 0.05 & -0.107 & -0.247 & -0.247 & -0.276 \\
\hline TDS & & & & & & & & & & & & & & & & 1 & 0.05 & 0.854 & 0.295 & -0.138 & -0.326 \\
\hline $\mathrm{F}$ & & & & & & & & & & & & & & & & & 1 & 0.05 & 0.05 & 0.05 & 0.05 \\
\hline TS & & & & & & & & & & & & & & & & & & 1 & 0.527 & -0.079 & -0.073 \\
\hline $\mathrm{CO}_{3}$ & & & & & & & & & & & & & & & & & & & 1 & 0.478 & 0.065 \\
\hline $\mathrm{HCO}_{3}$ & & & & & & & & & & & & & & & & & & & & 1 & -0.154 \\
\hline${ }^{\circ} \mathrm{C}$ & & & & & & & & & & & & & & & & & & & & & 1 \\
\hline
\end{tabular}

Bold letters indicate significant at the 0.05 level 
Table 3: Zooplankton diversity of Durgadahalli of Tumakuru.

\begin{tabular}{|c|c|}
\hline SL. No & Name of the species \\
\hline \multicolumn{2}{|r|}{ Rotifera : Brachionidae } \\
\hline 1 & Brachionus angularis Gosse, 1851 \\
\hline 2 & Brachionus calyciflorusPallas, 1766 \\
\hline 3 & Brachionus caudatus Barrois \& Daday, 1894 \\
\hline 4 & Brachionus dichotomus reductus Koste \& Shiel, 1980 \\
\hline 5 & Brachionus diversicornis (Daday, 1883) \\
\hline 6 & Brachionus falcatus Zacharias, 1898 \\
\hline 7 & Brachionus forficula Wierzejski, 1891 \\
\hline 8 & Brachionus quadridentatus quadridentatus Hermann, 1783 \\
\hline 9 & Keratella cochlearis (Gosse, 1851) \\
\hline 10 & Keratella tropica (Apstein, 1907) \\
\hline 11 & Platyias quadricornis (Ehrenberg, 1832) \\
\hline 12 & $\begin{array}{c}\text { Hexarthridae } \\
\text { Hexarthra intermedia Wiszniewski, } 1929\end{array}$ \\
\hline T13 & $\begin{array}{c}\text { Filiniidae } \\
\text { Filinia longiseta (Ehrenberg, 1834) }\end{array}$ \\
\hline 14 & $\begin{array}{c}\text { Asplanchnidae } \\
\text { Asplanchna brightwellii Gosse, } 1850\end{array}$ \\
\hline \multicolumn{2}{|r|}{ Cladocera } \\
\hline 15 & $\begin{array}{c}\text { Daphniidae } \\
\text { Ceriodaphnia cornuta Sars, } 1885\end{array}$ \\
\hline 16 & Daphnia (Ctenodaphnia) lumholtzi Sars, 1885 \\
\hline 17 & $\begin{array}{c}\text { Moinidae } \\
\text { Moina micrura Kurz, } 1875\end{array}$ \\
\hline 18 & Indialona ganapati Petkovski, 1966 \\
\hline \multicolumn{2}{|r|}{ Copepoda } \\
\hline 19 & Tropodiaptomus orientalis (Brady,1886) \\
\hline 20 & Neodiaptomus intermedius Flossner, 1984 \\
\hline
\end{tabular}

Table 4: Diversity of insects in Durgadahalli Lake

\begin{tabular}{|c|c|c|c|}
\hline Order & Family & Genus & Species \\
\hline \multirow{4}{*}{ Hemiptera } & Hydrometridae & $\begin{array}{c}\text { Hydrometra Latreille, } \\
1797\end{array}$ & - \\
\hline & Vellidae & Perittopus Fieber,1861 & - \\
\hline & Dytiscidae & $\begin{array}{c}\text { Lacconectus } \\
\text { Motschulsky, } 1855\end{array}$ & - \\
\hline & Hydraenidae & Ochthebius Leach, 1815 & - \\
\hline \multirow{3}{*}{ Odonata } & Chlorocyphidae & Libellago Chaudoir, 1878 & $\begin{array}{l}\text { L. andamanensis } \\
\text { Chaudoir, } 1878\end{array}$ \\
\hline & Gomphidae & GomphidiaFraser, 1923 & $\begin{array}{l}\text { G. kodaguensis } \\
\text { Fraser, } 1923\end{array}$ \\
\hline & Libellulidae & TrameaBrauer,1867 & $\begin{array}{l}\text { T. transmarine } \\
\text { Brauer, } 1867\end{array}$ \\
\hline \multirow[b]{2}{*}{ Diptera } & \multirow[b]{2}{*}{ Chironomidae } & Brillia Kieffer, 1913 & - \\
\hline & & $\begin{array}{c}\text { Chironomus Meigen, } \\
1803\end{array}$ & - \\
\hline
\end{tabular}

Table 5: Diversity of different fauna in Durgadahalli Lake.

\begin{tabular}{|c|c|c|}
\hline SI. No & Common name & Scientific name \\
\hline $\mathbf{1}$ & Shell of unio & Lamellidens consobrinus (Lea, 1860) \\
\hline $\mathbf{2}$ & Indian skittering frog & Euphlyctis cyanophlyctis(Schneider, 1799) \\
\hline $\mathbf{3}$ & Indian bull frog & Hoplobatrachus tigerinus(Daudin, 1803) \\
\hline $\mathbf{4}$ & Indian flapshell turtle & Lissemys punctata (Lacepede, 1788) \\
\hline
\end{tabular}

Table 6: Diversity indices calculated for the faunal diversity found in Durgadahalli Lake.

\begin{tabular}{|c|c|c|}
\hline SL. No & Diversity indices & Durgadahalli Lake \\
\hline 1 & Jaccard Similarity index (J) for Zoo plankton & 0.4583 \\
\hline 2 & Jaccard similarity index (J) for Diversity of insects & 0.256 \\
\hline 3 & $\begin{array}{c}\text { Jaccard similarity index (J) for Diversity of } \\
\text { Mollusca, Amphibia, Reptilia. }\end{array}$ & 0.4 \\
\hline
\end{tabular}

index (J) for Diversity of Mollusca is 0.4 (Table 6). Two species of frogs namely Euphlyctis cyanophlyctis [36] (Figure 3) and Hoplobatrachus tigerinus [37] of family Dicroglossidae commonly known as Indian skittering frog and Indian bull frog (Table 5) respectivelywere recorded. Jaccard similarity index (J) for Diversity of Amphibia is 0.4 (Table 6). Indian flap shell turtle identified as Lissemys punctata $[38,39]$ (Figure 4) belonging to order Testudinus and family Trionychidae (Table 5). Jaccard similarity index ( $\mathrm{J}$ ) for Diversity of Reptiles is 0.4 (Table 6).
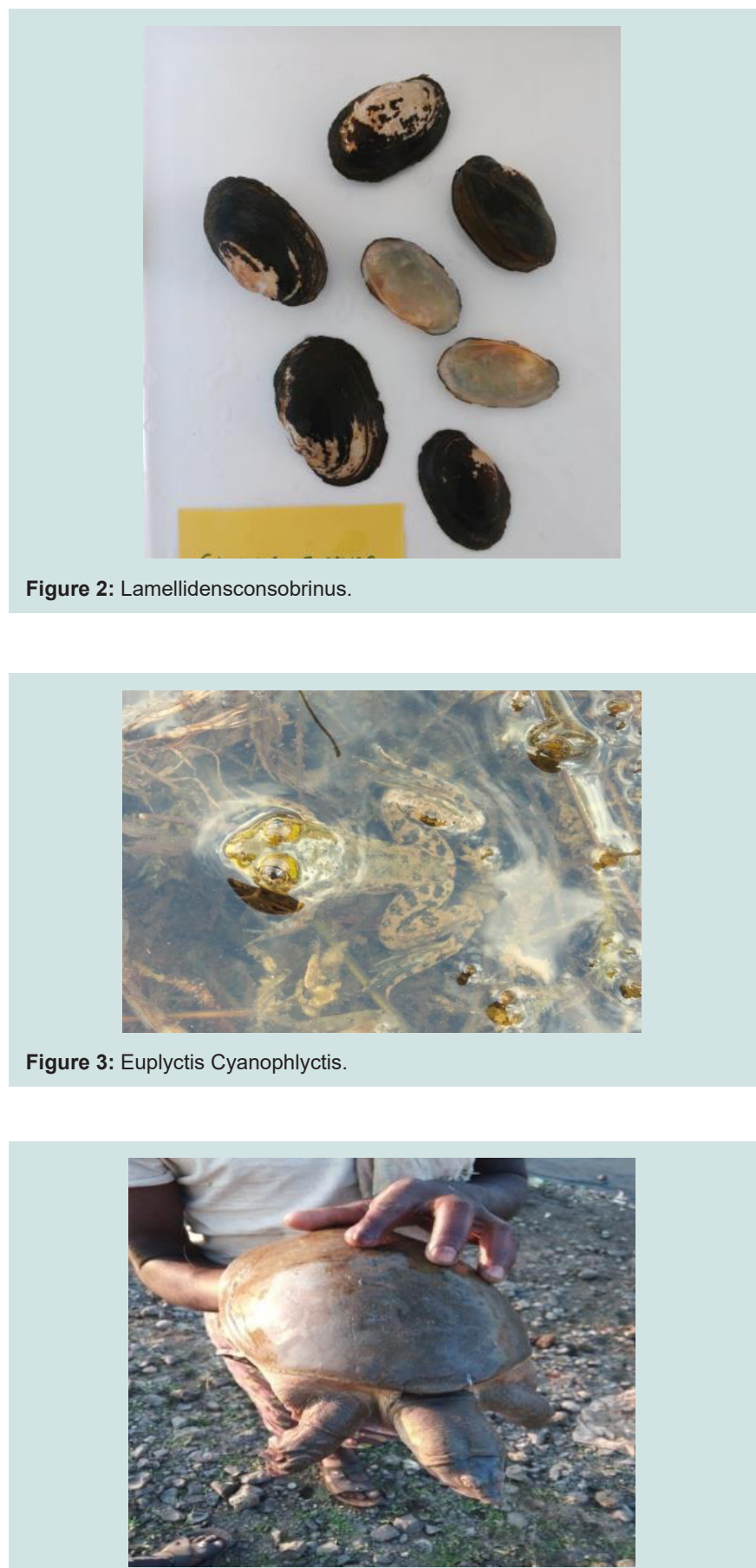

Figure 4: Lissemys punctate. 


\section{Conclusion}

The water of Durgadahalli lake is good for growth and survival of aquatic organisms. There is no such unpredictable change seen in the water throughout the study period, it is evidenced by identification of diversity of aquatic organisms. Planktons are the crucial source of food for many aquatic organisms like molluscans, fishes and other aquatic animals. Zooplankton is an important component in the aquatic food web acting as a trophic link between small particles and planktivorous fish [40-45]. Plankton are also good indicators of the health of the aquatic environment [46-48]. The phylum rotifera was the dominant, followed by cladocera and copepoda, family high number of species. The result influencing the diversity of other aquatic fauna because of the aquatic food chain. Major threats to global freshwater biodiversity are grouped into five categories like overexploitation, water pollution, flow modification, destruction or degradation of habitat and invasion by exotic species.

\section{Acknowledgement}

We express our sincere thanks to DOSR in Applied Zoology, Kuvempu University, Dept. of studies and Research in Environmental Science, Tumkur University and Government First Grade College, B.H Road, Tumakuru for providing the facility to carry out this research.

\section{References}

1. IUCN (1992) Protected areas of the world. Review of National systems. (4 Vol.) WCMC, Cambridge and IUCN Commission on National Parks and Protected Areas, IUCN. Gland, Switzerland.

2. Vaughn CC, Gido KB, Spooner dE (2004) Ecosystem processes performed by unionid mussels in stream mesocosms: species roles and effects of abundance. Hydrobiologia 527: 35-47.

3. Balian EV, Segers H, Laveeque C, Martens K (2008) The freshwater Animal diversity Assessment and overview of the results. Hydrobiologia 595: 627637.

4. Preston HB (1915) The fauna of British India: Mollusca (freshwater Gastropoda and Pelecypoda). London: Taylor and Francis, London. Xi + 244.

5. Strong EE, Gargominy O, Ponder WF, Bouchet P (2008) Global diversity of gastropods (Gastropoda : Mollusca) in freshwater. Hydrobiologia 595: 149166.

6. Subba Rao NV (1989). Handbook of Freshwater Molluscs of India. Zoological Survey of India, Kolkata. 289.

7. APHA (1998) Standard methods for the examination of the water and waste water $20^{\text {th }}$ Edition. American Public Health Association, Washington Aquaculture Engineering 19: 119-131.

8. Adoni AD (1985). Workbook on limnology. Pratibha Publishers, C-10, Gour Nagar, Sagar, India. 216.

9. Pouilly M, Barrera S, Rosales C (2006) Changes of taxonomic and trophic structure of fish assemblages along an environmental gradient in the upper Beni watershed (Bolivia) J Fish Biol 68: 137-156.

10. Marsh-Matthews E, Matthews WJ (2000) Geographic, terrestrial and aquatic factors: which most influence structure of Midwestern USA stream fish assemblages? Ecol Fresh. Fish 9: 13-21.

11. Poff NL, Allan JD (1995). Functional organization of stream fish assemblages in relation to hydro biological variability. Ecology 76: 606- 627.

12. Martin-Smith KM (1998). Relationships between fishes and habitat in rain forest streams in Sabah, Malaysia. J Fish Boil 52: 458-482.

13. Walters DM, Leigh DS, Freeman MC, Freeman BJ, Pringle CM (2003).
Geomorphology and fish assemblages in a Piedmont river basin, U. S. A. Freshwater Biology 48: 1950-1970.

14. Taylor CM (2000). A large-scale comparative analysis of riffle and pool fish communities in an upland stream system. Environ. Biol Fish 58: 89- 95.

15. Ibanez C, Oberdorff T, Teugels G, Mamononekene V, Lavoueacute S, et al. (2007). Fish assemblage structure and function along environmental gradients in rivers of Gabon (Africa). Ecology of Freshwater Fish (16-3): 315334.

16. Valerio SB, Suarez YR, Felipe TRA, Tondato KK, Ximenes LQL (2007) Organization patterns of headwater- stream fish communities in the upper Paraguay- Parana basins. Hydrobiologia, 583: 1- 241.

17. Rashleigh B (2004) Relation of environmental characteristics to fish assemblages in the upper French broad river basin, North Carolina. Environ. Monitoring and Assessment 93: 139-156.

18. Lenat DR, Crawford JK (1994) Effects of land use on water quality and aquatic biotic of three North Carolina Piedmont streams. Hydrobiologia 294: 185-199.

19. Clinton BD, Vose JN (2006) Variation in stream water quality in an urban headwater stream in the southern Appalachians, Water Air and Soil Pollution 169: 339-353.

20. Karuthapandi M, Rao DV, Xavier InnocentB (2016a) Zooplankton Diversity and Physicochemical Profile of Ameenpur Tank, Telangana, India. Rec Zool Surv India 116: 347-366.

21. Karuthapandi M, Rao DV, Xavier Innocent B (2016b) Zooplankton Composition, Diversity and Physicochemical Features of Bandam Kommu Pond, Medak District, Telangana, India. Proc Zool Soc 69: 189-204.

22. Chopra G, Jakhar P (2016) Diversity and Community Composition of Zooplankton in three Wetlands of Fatehabad, Haryana. Curr World Environ 11.

23. Karuthapandi M, Rao D.V, Xavier Innocent (2018). Zooplankton Diversity of Osmansagar Reservoir, Telangana, India. Proc Zool Soc. 71: 229-238.

24. Polhemus JT, Polhemus DA (2008) Global diversity of true bugs (Heteroptera: Insecta) in freshwater. Hydrobiologia 595: 379-391.

25. Alder PH, Foottit RG (2009) Introduction. In: Insect Biodiversity Science and Society, Fottit, R.G. and P.H. Alder (Eds.). A John Weileys \& Sons, Ltd. Publications., 3.

26. Polhemus JT, Polhemus DA (2007) Global trends in the description of aquatic and semi-aquatic Heteroptera species, 1758-2004. Tijdschrift voor Entomologie 150: 271-288.

27. Thirumalai G (1999) Aquatic and semi-aquatic Heteroptera (Insecta) of India. Indian Association of Aquatic Biologists (IAAB) Publication No 7: 1-74.

28. Thirumalai G (2002) A checklist of Gerromorpha (Hemiptera) from India. Rec. Zoo. Sur. India. 100 (Part 1-2): 55-97.

29. Thirumalai G (2007) A synoptic list of Nepomorpha (Hemiptera: Heteroptera) from India. Records of the Zoological Survey of India Occasional Paper No. 273: 1-84.

30. Hungerford HB, Matsuda R (1958a) The Tenagogonus-Limnometra. Complex of the gerrinae. Kansas University Science Bulletin 39: 371- 457.

31. Hungerford HB, Matsuda R (1958b) A new primitive Ptilomera from the Himalaya and other notes (Gerridae, Hemiptera). Bulletin of the Brooklyn Entomological Society 53: 117-123.

32. Prabhaka,Choodamani KA (2018) Aquatic insect diversity of fresh water body at katphal Lake, tal- sangola, distsolapur (m.s.). India. Ind J Res 7: 26-27.

33. Devi BM, Sandhyarani Devi O, Wahengbam L (2015). Analysis of Aquatic Insect Communities of Loktak Lake and its PhysicoChemical Properties. Int JScie Res 4: 368-376.

34. Jordon KHC (1951) Zoogeographisce Betrachtungen uber das ostiliche Sachsen dargestelit and entschen Neuf under von Heteropteren. Zoologischer Anzeiger 147: 79-84. 
Citation: Shivaraju, Venkateshwarlu M. Faunal Diversity of Durgadahalli Lake of Tumakuru, Karnataka State, India. J Environ Stud. 2021;7(1): 6.

\section{ISSN: $2471-4879$}

35. Lea I (1860) Descriptions of Three New Species of Exotic Uniones. Proc Acad. Nat. Sci. Philadelphia 11: 313.

36. Schneider JG (1799). Historiae Amphibiorum narturalis et literariae. Fasciculus primus, continens Ranas. Calamitas, Bufones, Salamandras et Hydros. Frommanni, Jena 266.

37. Lacepede B G E (1788). Natural History of the Quadrupe of the Oviparous and Serpens. Vol. 1. Imprimerie du Roi, Hotel de Thou, Paris, xvii + 651

38. Banse K(1995) Zooplankton: pivotal role in the control of ocean production. ICES J Mar Sci 52: 265-277.

39. Correll DL (1978). Estuarine productivity. Bioscience 28: 646-650.

40. Daudin F M (1802). Histoire Naturelle, generale et particulieredes reptiles, ouvrage faisant suite, a histoiure naturelle, generale et particuliere composee par Leclerc de Buffon, et redigee par C. S. Sonnini, 3 Dufart, Paris.

41. Giske J, Aksnes DL, Balino BM, Kaartvedt S, Lie U, et al. (1990). Vertical distribution and trophic interactions of zooplankton and fish in Masfjorden, Norway. Sarsia 75: 65-81.

42. Buskey EJ (1993) Annual pattern of micro- and mesozoo plankton abundance and biomass in a subtropical estuary. J Plankton Res 15: 907-924.
43. Morgan CA, Cordell JR, Simenstad CA (1997). Sink or swim? Copepod population maintenance in the Columbia River estuarine turbidity-maxima region. Mar Biol 129: 309-317.

44. Froneman PW (2000) Preliminary study of the food web structure of two contrasting estuaries along the Eastern Cape coast. S Afr J Aquat Sci 25: 13-22.

45. Froneman, PW (2003) Food web dynamics in a temperate temporarily open/ closed estuary (South Africa). Estuar. Coast Shelf Sci 59: 87-95.

46. Downing JA, Perusse M, Frenette $Y$ (1987). Effects of inter replicate variance on zooplankton sampling design and data analysis. LimnolOceanogr 323: 673- 680.

47. Schlacher T, Wooldridge TH (1995) Small scale distribution and variability of demersal zooplankton in a shallow temperate estuary: tidal and depth effects on species-specific heterogeneity. Cah Biol Mar 36: 211-227.

48. Kibirige I, R. Perissinotto (2003) The zooplankton community of the Mepanjati Estuary, a South African temporarily open/closed system. Estuar Coast Shelf Sci 58: 724-741. 